\title{
Maternal mRNA from clam oocytes can be specifically unmasked in vitro by antisense RNA complementary to the $3^{\prime}$-untranslated region
}

\author{
Nancy Standart, Martin Dale, Elspeth Stewart, and Tim Hunt \\ Department of Biochemistry, University of Cambridge, Cambridge CB2 1QW, UK
}

\begin{abstract}
Clam oocytes display a striking difference in the pattern of protein synthesis on fertilization, which is maintained when cell-free extracts are assayed in the rabbit reticulocyte lysate. The mRNAs encoding ribonucleotide reductase and cyclin $\mathrm{A}$ (the major masked messages in the oocyte extracts) can be translationally activated by gel filtration in $0.5 \mathrm{~m} \mathrm{KCl}$, presumably by removal of repressor protein(s). When synthetic RNAs corresponding to different segments of ribonucleotide reductase and cyclin A mRNAs were added to oocyte extracts in $0.5 \mathrm{M} \mathrm{KCl}$ in a "competitive unmasking" assay, specific and complete unmasking of these mRNAs occurred on addition of antisense 3 '-noncoding transcripts. The unmasking region in ribonucleotide reductase mRNA maps to a region of 134 nucleotides centered one-third of the way down the 3 -noncoding region.
\end{abstract}

[Key Words: Antisense RNA; cyclin; maternal mRNA; oligonucleotides; polyadenylation; ribonucleotide reductase; translational control]

Received July 23, 1990; revised version accepted September 13, 1990.

The pattern of protein synthesis in oocytes of the clam, Spisula solidissima changes dramatically during meiotic maturation, which is normally triggered by fertilization in this organism. Within minutes, synthesis of several of the prominent proteins made by the oocyte stops and the synthesis of new proteins starts. This switch is regulated entirely at the translational level; the translation patterns encoded by mRNA extracted from oocytes and early embryos are identical (Rosenthal et al. 1980). It has subsequently emerged that translational regulation of gene expression almost always accompanies meiotic maturation of oocytes - this is true of starfish (Rosenthal et al. 1982; Standart et al. 1987), sea urchins (Grainger et al. 1986), frogs (Dworkin et al. 1985; Hyman and Wormington 1988; McGrew et al. 1989), and mice (Huarte et al. 1987; Paynton et al. 1988). In Drosophila, the localization of particular maternal mRNAs in the egg is important for setting up the embryonic axis, and translational control is probably involved, since bicoid protein cannot be detected at any stage during oogenesis despite the presence of its mRNA (Driever and Nüsslein-Volhard 1988).

Cyclins and the small subunit of ribonucleotide reductase are among the proteins whose synthesis is initiated by fertilization of clam oocytes (Evans et al. 1983; Standart et al. 1985; Swenson et al. 1986; Westendorf et al. 1989). These maternal mRNAs provide the cleavagestage embryo with proteins and enzymes necessary to

This paper is dedicated to the memory of Steve Prentis. sustain rapid cell division (Grainger et al. 1986). Some of the maternal mRNAs whose translation stops after fertilization have also been identified. They encode abundant cellular components such as actin, tubulin, and ribosomal proteins in a variety of organisms (Rosenthal et al. 1983; Grainger et al. 1986; Standart et al. 1987; Hyman and Wormington 1988; Paynton et al. 1988).

Thus, a control mechanism capable of distinguishing individual messages or sets of mRNA must exist, and several models have been proposed to explain its molecular basis. For example, it has been suggested that the stored mRNA is only partially processed, containing introns and lacking the $5^{\prime}$ cap structure and the $3^{\prime}$ poly(A) tail (Caldwell and Emerson 1985; Davidson 1986; Richter 1987). The translationally regulated maternal mRNAs that have been studied in clams, frogs, and mice do not undergo large size changes, however (Huarte et al. 1987; Rosenthal and Wilt 1987; Hyman and Wormington 1988), or change their translatability in vitro after maturation or fertilization. It is thus unlikely that modifications such as delayed splicing or addition of the 5' cap structure to preexisting uncapped mRNA are involved in translational activation. During the meiotic maturation of oocytes, however, it is almost always true that the mRNAs recruited onto polysomes undergo lengthening of their poly(A) tails. At the same time, the mRNAs that stop being translated lose AMP residues from their $3^{\prime}$ end, or in some cases become completely deadenylated (for review, see Rosenthal and Wilt 1987; Jackson and Standart 1990). Despite this clear-cut tem- 
poral correlation, it is not well understood how polyadenylation affects the translation of these mRNAs. This point is explored further in the Discussion.

The first model for translational control in embryos was proposed in 1966 by Spirin, who noted that maternal mRNA was associated with proteins (Spirin 1966). He suggested that these proteins acted as translational inhibitors, which were released or inactivated upon meiotic maturation or fertilization. This "masked mRNA" model received experimental support when Jenkins et al. (1978) and Ilan and Ilan (1978) found that sea urchin egg mRNP could not be translated in vitro, although RNA extracted from the mRNP was actively translated. Although Moon et al. (1982) failed to reproduce these findings, possibly due to variations in the mRNP isolation and assay procedures, use of large-pore gel filtration columns permitted the isolation of masked mRNP from sea urchin eggs that could be activated by high salt. This was in substantial agreement with the earlier results and consistent with Spirin's conjecture (Grainger and Winkler 1987).

There is a tacit assumption that because masking blocks initiation of translation, the masking proteins must interact with determinants at or near the $5^{\prime}$ end of the mRNA. This is certainly true of ferritin mRNA, in which a regulatory protein binds to a conserved stemloop structure in the $5^{\prime}$-noncoding region (Aziz and Munro 1987; Hentze et al. 1987; Walden et al. 1989; for review, see Munro and Eisenstein 1989). Neither of the clam mRNAs reported in this paper contain upstream AUG codons that might indicate the operation of a control mechanism like the one found in the GCN4 gene of Saccharomyces cerevisiae (Hinnebusch 1988).

We show that translational repression of clam maternal mRNA is maintained in cell-free extracts and that nonspecific unmasking can be achieved by gel filtration in high salt. More surprisingly, we show that specific unmasking of ribonucleotide reductase and cyclin A mRNAs can be achieved by the addition of antisense RNA transcripts of cDNA subclones corresponding to short sequences in their $3^{\prime}$-untranslated regions. Presumably, these regions are associated with "masking" proteins.

\section{Results}

When postmitochondrial extracts from clam oocytes or activated eggs were mixed with four volumes of nuclease-treated rabbit reticulocyte lysate, the pattern of proteins programmed by the oocyte extract was strikingly different from that encoded by the activated egg extract (Fig. 1, lanes 1 and 2, respectively). This confirms the previous results of Rosenthal et al. (1980). In particular, the small subunit of ribonucleotide reductase (Standart et al. 1985) and cyclin A (Swenson et al. 1986) (denoted RR and A, respectively, in Fig. 1) were made at low levels in the assay containing oocyte extract and strongly synthesized when activated egg extract was used. Certain unidentified polypeptides, marked by arrows, showed reduced synthesis in the activated egg

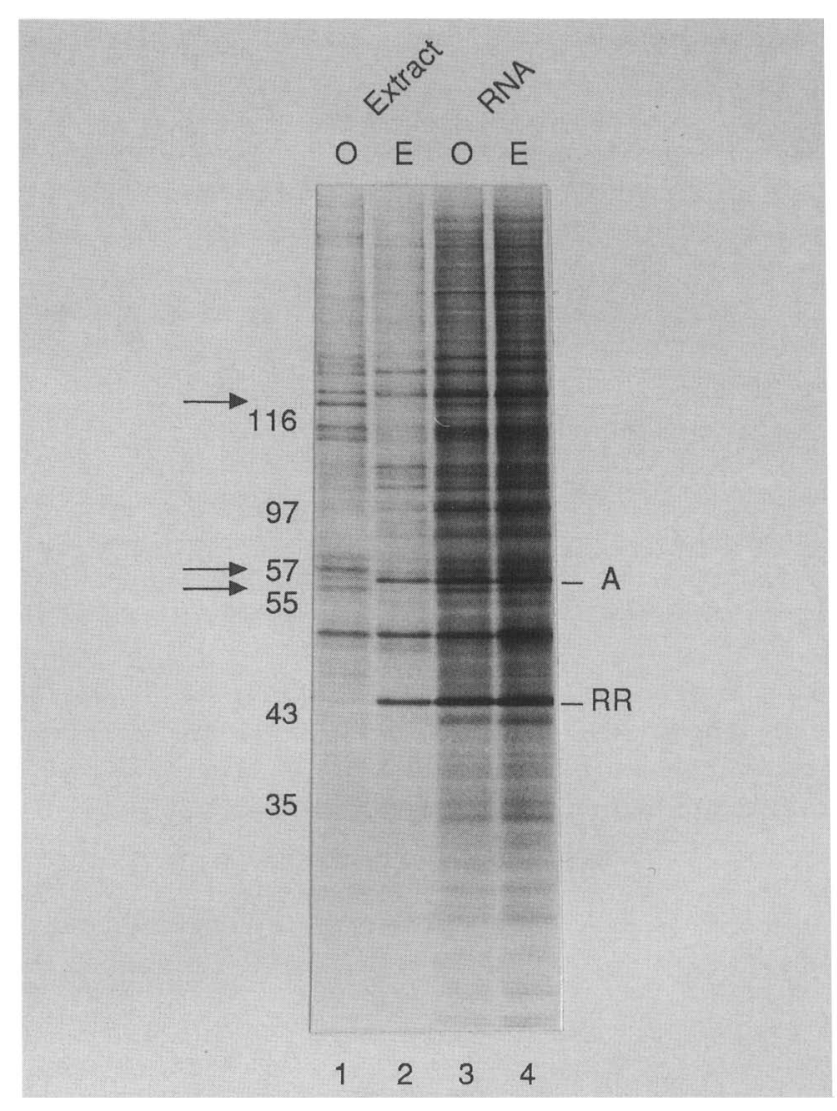

Figure 1. Clam maternal mRNAs are masked in cell-free oocyte extracts. Extracts of oocytes (lane 1) or activated eggs (lane 2) were mixed with 4 volumes of nuclease-treated rabbit reticulocyte lysate and translated in vitro. The translation products were analyzed by SDS-PAGE electrophoresis and autoradiography. (Lanes 3 and 4) Cell-free translation products directed by phenol-extracted RNA from unfertilized and activated oocytes, respectively. The sizes of molecular weight markers are indicated in $\mathrm{kD}$. (A) Cyclin $\mathrm{A}$; (RR) small subunit of ribonucleotide reductase. Examples of proteins that are synthesized before activation and reduced or absent after activation are indicated by arrows.

extract compared with the oocyte extract. When mRNA was extracted from the two kinds of clam extracts and translated in the reticulocyte lysate (Fig. 1, lanes 3 and 4 ), the patterns of products were essentially identical. Thus, the mRNAs for ribonucleotide reductase and cyclin A are present but masked in the clam oocyte cellfree extracts. Because the masking factors are removed by standard RNA extraction procedures, they are most likely proteins.

\section{Repressed mRNAs can be unmasked by gel filtration in high-salt buffer}

RNA-protein interactions are apt to be salt sensitive, and incubation in high-salt $(0.5 \mathrm{M} \mathrm{KCl})$ buffer (HSB) would be expected to dissociate the proteins from the mRNA. Subsequent gel filtration should separate these putative repressors from the mRNA/Grainger and 
Winkler 1987). To test this, an oocyte extract was made $0.5 \mathrm{M}$ in $\mathrm{KCl}$ and loaded onto a column of Sepharose CL6B equilibrated in HSB. Figure 2A shows that three peaks were eluted: an excluded ribosome/mRNP peak, a broad protein peak, and a third and final peak of low-molecular-weight, UV-absorbing molecules, largely ATP.

The excluded RNP fractions from this run and from a parallel column run in low-salt buffer (LSB) were assayed by translation with reticulocyte lysate, adjusting the $\mathrm{KCl}$ concentration to $100 \mathrm{mM}$ in the final mixture in all cases. Figure $2 \mathrm{~B}$ shows that the combination of high salt and gel filtration activated translation of the masked oocyte mRNAs, giving an overall pattern of protein synthesis resembling that seen with the activated egg extracts (lanes 1 and 4). This is particularly clear for ribonucleotide reductase and cyclin A mRNAs. Gel filtration in low salt (lane 2) or addition of $0.5 \mathrm{M} \mathrm{KCl}$ without subsequent gel filtration (lane 3) did not lead to unmasking.

These data implied that repressor proteins were detached from the mRNA by high salt but could rebind efficiently and remask the mRNA unless the components were separated from each other by gel filtration. The RNP peak from a low-salt column could be translationally activated by a second round of gel filtration in high salt (not shown), implying that unmasking did not require low-molecular-weight cofactors.

We were unable to obtain specific remasking of total, phenol-extracted RNA or of the mRNP fraction from the high-salt Sepharose column by adding the retarded fractions from the high-salt gel filtration column. Our efforts were hampered by the nonspecific inhibition of translation shown by some fractions, but we tentatively concluded that either more than one factor must be involved or that some special conditions are required for masking.

\section{Ribonucleotide reductase $m R N A$ can be specifically unmasked with antisense RNA}

As an alternative to directly purifying masking factors, we focused our efforts on identifying the regions of the mRNA that were required for specific masking. Based on the results of the gel filtration experiments and the assumption that the putative repressor proteins bind the masked mRNAs specifically, we thought it should be possible to activate the masked mRNA in oocyte extracts by raising the salt concentration and adding synthetic RNA competitors. We anticipated that the repressors would distribute themselves between the endogenous mRNA and the competitor RNA fragments and, hence, unmask the mRNA. Accordingly, portions of ribonucleotide reductase cDNA were subcloned into pGEM transcription vectors as indicated in Figure 3A. The complete 5 '-noncoding region, a portion of the coding region, and the complete $3^{\prime}$-noncoding regions of ribonucleotide reductase mRNA were placed in both orientations to give sense and antisense transcripts when transcribed by T7 RNA polymerase. These transcripts are referred to as S5 and A5 (5'-noncoding sense and antisense), SC and AC (coding sense and antisense), and S3 and A3 ( 3 '-noncoding sense and antisense). To avoid possible complications of competition for the cap-binding protein, the transcripts used in the unmasking assay were uncapped unless otherwise stated. rRNAs from Escherichia coli, poly $(\mathrm{A})$ and poly $(\mathrm{U})$ were used as additional controls in these experiments.
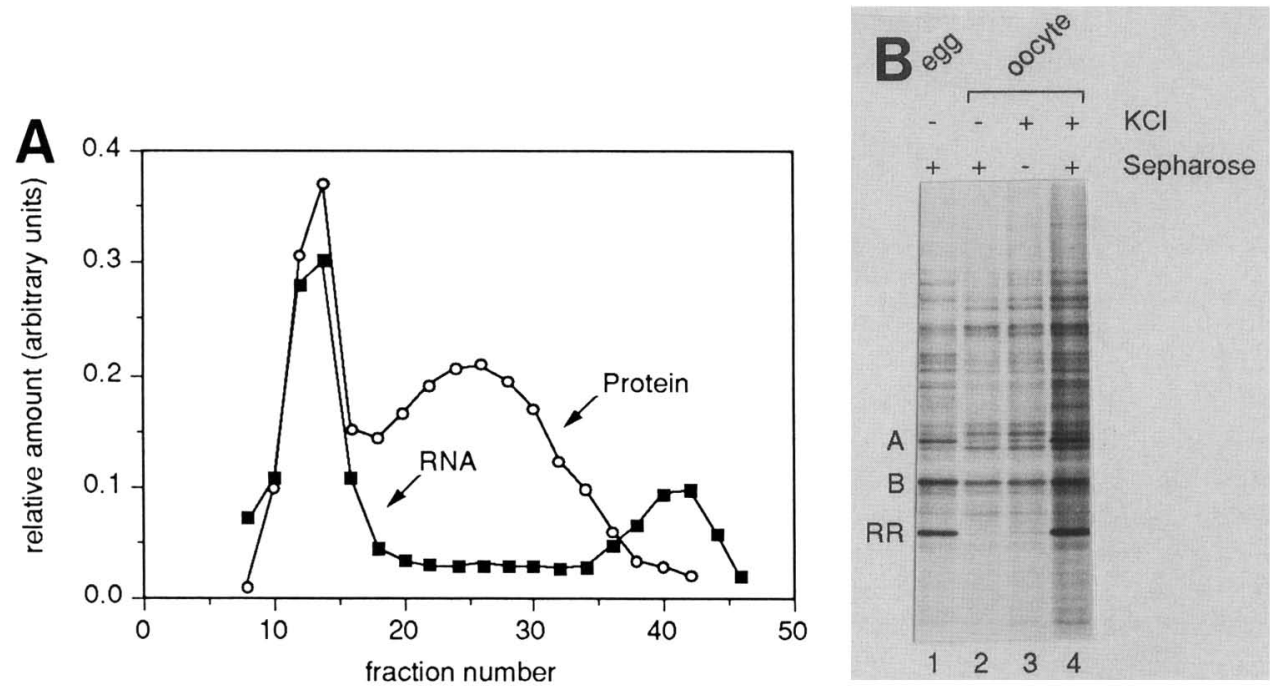

Figure 2. Gel filtration in HSB unmasks oocyte mRNAs. (A) Gel filtration profile of a clam oocyte extract on Sepharose CL6B. RNA was determind by absorbance at $260 \mathrm{~nm}$. Protein was determined by the method of Bradford (1976). This profile was essentially the same in both HSB and LSB. (B) The in vitro translation patterns of activated egg (lane 1) and oocyte (lanes 2-4) extracts in the reticulocyte lysate as shown. The excluded peak of a Sepharose column run in low salt (lane 2) and high salt (lane 4) was assayed in the reticulocyte lysate. (Lane 3) The pattern of protein synthesis when an oocyte extract was incubated in $0.5 \mathrm{M} \mathrm{KCl}$ but not gel filtered. The bands corresponding to cyclins $\mathrm{A}$ and $\mathrm{B}$ and the small subunit of ribonucleotide reductase (RR) are indicated at left. 
A
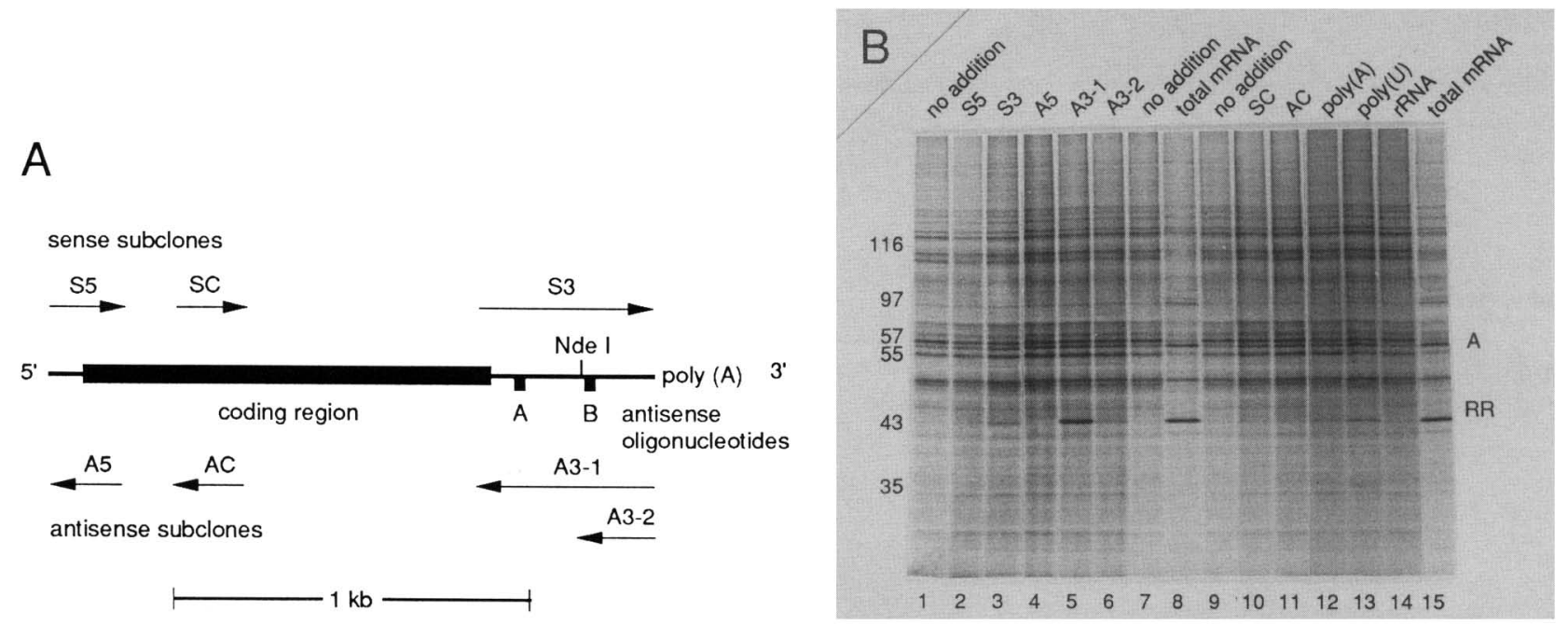

Figure 3. Antisense RNA corresponding to the $3^{\prime}$-noncoding region of ribonucleotide reductase mRNA activates its translation in vitro. (A) A map of clam ribonucleotide reductase small subunit mRNA. Portions of this mRNA were subcloned into pGEM plasmids for transcription with T7 RNA polymerase (for details, see Materials and methods). The length and sense of each transcript is indicated; (S5/A5) Sense/antisense 5'-untranslated region transcripts; (SC/AC) Sense/antisense-coding region transcripts; (S3/A3-1) sense/ antisense full-length $3^{\prime}$-untranslated region transcripts. Plasmid A3-1 was linearized with NdeI to give the truncated A3-2 transcript. The location of the two antisense oligonucleotides, A and B, described in Fig. 6, is shown. (B) Activation of ribonucleotide reductase translation in the unmasking assay. Oocyte mRNPs were incubated at $0.5 \mathrm{M} \mathrm{KCl}$ with various synthetic RNAs, as detailed above each track, and mixed with reticulocyte lysate for assay of protein synthesis. (Lanes 8 and 15) Pattern of translation given by total oocyte phenol-extracted $\mathrm{RNA}_{i}$ (lanes 1,7, and 9) pattern of translation given by the oocyte mRNP without any competitor transcript.

For the unmasking assay, oocyte mRNP fractions were made $0.5 \mathrm{M}$ in $\mathrm{KCl}$ and mixed with competitor RNA. Reticulocyte lysate was added and the samples were incubated at $20^{\circ} \mathrm{C}$ for about $3 \mathrm{~min}$ and then at $30^{\circ} \mathrm{C}$ for $60 \mathrm{~min}$. Figure 3B shows the results of an unmasking assay. The synthesis of ribonucleotide reductase in total phenol-extracted RNA served as a positive control (lanes 8 and 15). Lane 5 shows that quantitative unmasking of ribonucleotide reductase mRNA was brought about by addition of the antisense 3' UTR transcript, A3-1. The equivalent sense transcript (S3) showed low but reproducible specific stimulation of ribonucleotide reductase synthesis (lane 3). Poly(A) and poly(U) (lanes 12 and 13, respectively) also showed low but reproducible unmasking activity. However, none of the other competitors we tested - the $5^{\prime}$ UTR transcripts (S5 and A5, lanes 2 and 4), the coding transcripts (SC and $A C$, lanes 10 and 11), and rRNA (lane 14) - had any significant effect on translation. Simultaneous addition of the $5^{\prime}$ and $3^{\prime}$ UTR sense transcripts, whether as separate molecules or as a single transcript from a plasmid construct from which the coding region had been excised, did not lead to any greater unmasking than that shown by the $3^{\prime}$ UTR sense transcript alone (not shown). We concluded that only the antisense $3^{\prime}$ UTR transcript was capable of unmasking all of the masked ribonucleotide reductase mRNA in the mRNP fraction. The unmasking effect was specific for ribonucleotide reductase mRNA.

We next asked whether the high-salt treatment was necessary, and determined what concentration of the $3^{\prime}$ UTR antisense transcript was required for complete unmasking of ribonucleotide reductase mRNA. As shown in Figure 4, the addition of high salt led to approximately threefold greater degree of unmasking when the antisense RNA (A3-1) was added compared with low-salt incubation (cf. lanes 2-5 with lanes 7-10). Full unmasking was observed at $\sim 12-25 \mu \mathrm{g} / \mathrm{ml}$ antisense RNA (lanes 7 and 8), and only partial unmasking activity was observed at $\sim 3 \mu \mathrm{g} / \mathrm{ml}$ (lane 10). The efficiency of unmasking thus depends on both the antisense RNA concentration and the pretreatment of the oocyte mRNP with high salt. We calculated that the lowest concentration of the $3^{\prime}$ UTR transcript capable of complete un-

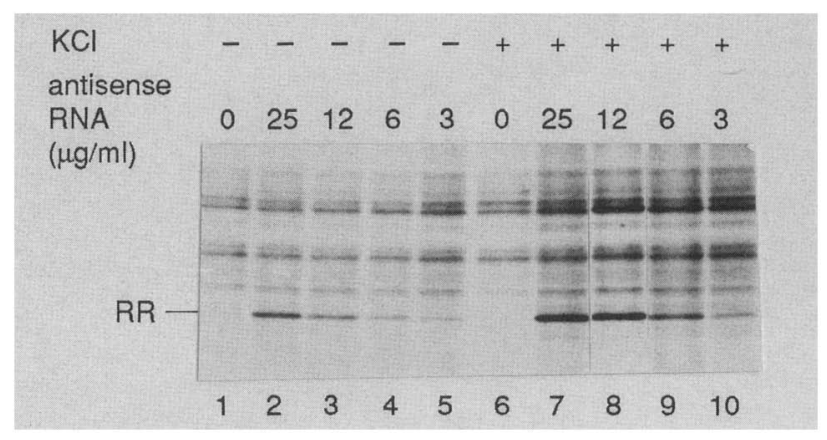

Figure 4. The degree of unmasking is dependent on high salt and on antisense RNA concentration. Oocyte mRNPs were incubated with (lanes 6-10) or without (lanes 1-5) added $0.5 \mathrm{M}$ $\mathrm{KCl}$ and increasing concentrations of the antisense 3 ' transcript of ribonucleotide reductase mRNA, as indicated. The position of ribonucleotide reductase is indicated at left. Only the area of the autoradiograph containing ribonucleotide reductase is shown. 
masking is $\sim 100$-fold molar excess over the mRNA, but significant unmasking is seen at lower concentrations. One possible explanation for the relatively high concentration of antisense RNA required for unmasking was that the competitor transcripts were unstable in the mixed assay system. However, capping the antisense transcript, which would be expected to stabilize it, actually reduced its effectiveness as an unmasking agent (not shown).

The masking element in ribonucleotide reductase $m R N A$ is contained in a stretch of 134 nucleotides that starts 80 nucleotides downstream of the coding region

A rough definition of the portion of the $3^{\prime}$-noncoding region necessary for unmasking was obtained by linearizing the A3-1 pGEM plasmid with NdeI (see Fig. 3A). This truncated antisense transcript A3-2 (Fig. 3B, lane 6) showed hardly any activity. This suggested that the unmasking sequence lay between the end of the coding region and this NdeI site (situated about halfway along the noncoding region). This tentative assignment was strengthened by results from the weak but detectable activity of sense $3^{\prime}$ transcripts, which was only observed with fragments extending from the end of the coding region to the NdeI site (not shown).

To define the active region more precisely, a set of exonuclease III deletion clones was constructed. The $5^{\prime}$ boundary was defined by unidirectional deletions starting at the $5^{\prime}$ end of plasmid A3-1 extending to the NdeI site (Fig. 5A). Ten of these clones were transcribed with T7 RNA polymerase to give antisense RNA and were tested for unmasking activity. Figure $5 \mathrm{~B}$ shows that the best unmasking activity was obtained with the longest transcripts (lanes $2-6 ; 5^{\prime}$ boundaries from -13 to 83 with respect to the end of the coding region). The shorter transcripts 6 and 7 showed intermediate activity (lanes 7 and $8 ; 5^{\prime}$ boundaries at 123 and 146), whereas the three shortest transcripts had little or no unmasking activity (lanes $9-11 ; 5^{\prime}$ boundaries $180-254$ ). We noticed that the full-length 3' UTR transcript, clone 1 (lane 2), showed less unmasking activity than clones 2-5 (lanes 3-6), perhaps because the full-length transcript extends 13 nucleotides into the protein-coding region. This may impair translation of the unmasked mRNA slightly.

Removal of distal sequences (downstream of the NdeI site at position 254) from selected 5' deletion clones (see Materials and methods) did not impair their unmasking activity (data not shown). Thus, the unmasking sequence must start at position 83 and extend no farther than 254 residues into the $3^{\prime}$ UTR as defined by the shortest $5^{\prime}$ deletion clone showing full unmasking activity (Fig. 5B, clone 5). To define the $3^{\prime}$ border of the unmasking element, a second set of exonuclease III deletion clones was prepared, with bidirectional deletions starting at the NdeI site of clone 5 (Fig. 5A). The shortest antisense transcript that gave essentially full unmasking

A constructs
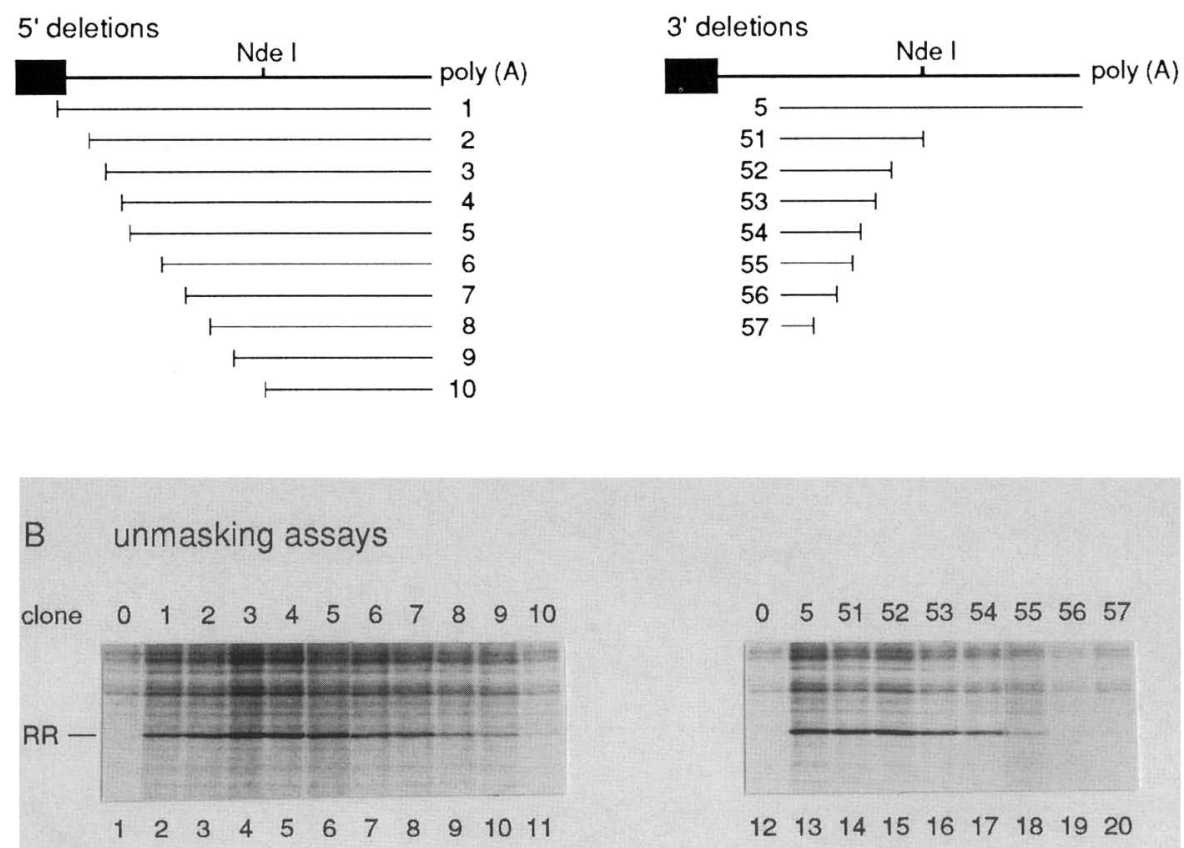

$\begin{array}{lllllllll}0 & 5 & 51 & 52 & 53 & 54 & 55 & 56 & 57\end{array}$

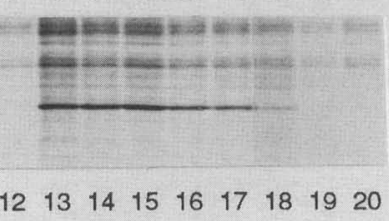

Figure 5. The unmasking signal can be mapped to a 134-nucleotide region of the $3^{\prime}$ UTR. (A) Diagram of the $5^{\prime}$ and $3^{\prime}$ exonuclease III deletions; $(B)$ assay of antisense RNA transcribed from these deletions for their ability to activate the synthesis of ribonucleotide reductase $(\mathrm{RR})$ in the mixed clam reticulocyte translation assay. 
was obtained from clone $5-2$, which contained 134 bases of the 3' UTR from position 83-217 (Fig. 5B, lane 15). This region ends $\sim 250$ nucleotides upstream of the poly|A| tail.

Detachment of the $3^{\prime}$ UTR with antisense oligonucleotides and RNase $H$ stimulates translation of ribonucleotide reductase $m R N A$

If a region of mRNA in the $3^{\prime}$ UTR is required for masking, detaching it from the body of the mRNA should result in unmasking. To test this, we added antisense oligonucleotides directed against portions of the $3^{\prime}$ UTR of ribonucleotide reductase mRNA, together with RNase $\mathrm{H}$ to cut the RNA strand of the DNA/RNA hybrids. Two antisense oligonucleotides ( $\mathrm{A}$ and $\mathrm{B})$ were directed against the 3' UTR; their location is shown in Figure 3A. Each oligonucleotide was added to the oocyte extract at increasing concentrations, with the results shown in Figure 6A. Oligonucleotide A, located at the $5^{\prime}$ boundary of the unmasking sequence, resulted in a significant degree of specific unmasking (lanes 2-4) although high concentrations $(0.1-0.6 \mathrm{mg} / \mathrm{ml})$ were required to see an effect. This may reflect protection of the RNA sequence by secondary structure and bound proteins, since we normally find that $10-100 \mu \mathrm{g} / \mathrm{ml}$ of antisense oligonucleotides is enough to give complete cutting of mRNA in crude extracts (see legend to Fig. 6 for note on the inhibition of synthesis of a $116-\mathrm{kD}$ polypeptide by oligonucleotide A). On the other hand, the more distal oligonucleotide $\mathrm{B}$ did not stimulate ribonucleotide reductase synthesis (Fig. 6, lanes 5-7). Oligonucleotide B was located just downstream of the NdeI site, so that the "masking region" would still be attached to the mRNA after cutting.

To confirm that the oligonucleotides cut the mRNA as expected, RNA was prepared from the translation assays with and without added oligonucleotides and analyzed by Northern blotting. Addition of the antisense oligonucleotides led to loss of the $1.7-\mathrm{kb}$ full-length ribonucleotide reductase mRNA, and the appearance of a 500-nucleotide $3^{\prime}$ fragment in the case of oligonucleotide $\mathrm{A}$ and a 300-nucleotide $3^{\prime}$ fragment in the case of oligonucleotide B (data not shown). We interpret these results as providing support for the conclusion that a key masking sequence lies between 83 and 217 residues of the 454-residue-long 3' UTR of ribonucleotide reductase mRNA. As far as we know, this is the only known example of antisense oligonucleotides stimulating translation of a specifically targeted mRNA.

\section{Unmasking of ribonucleotide reductase mRNA in vitro is not linked to polyadenylation}

In living embryos, translational activation of ribonucleotide reductase mRNA occurs at the same time as the lengthening of its poly(A) tail (see previous references). In unfertilized oocytes, ribonucleotide reductase and cyclin A mRNAs have short poly(A) tails and they bind poorly (if at all) to oligo(dT)-cellulose (Rosenthal et al.
1983). To test whether the unmasking of mRNA in vitro was associated with polyadenylation, we isolated RNA by phenol extraction of the excluded peak from the high-salt gel filtration column that led to the activation of masked mRNA (see Fig. 2). This RNA was separated into poly $(\mathrm{A})^{-}$and poly $(\mathrm{A})^{+}$classes by oligo(dT)-cellulose chromatography and translated in a rabbit reticulocyte lysate. Oocyte and embryo total RNA were fractionated in parallel. As shown in Figure 7A, ribonucleotide reductase mRNA and cyclin A mRNA are almost completely $\operatorname{poly}(\mathrm{A})$ - in the oocyte (lanes $1-3)$ and shift to the poly $\mid A)^{+}$fraction in egg extracts (lanes $\left.4-6\right)$. The in vitro-activated mRNAs remained predominantly in the poly $(A)^{-}$class (lanes 7-9), however, showing that in vitro activation occurs without extensive polyadenylation.

Presumably, it would be impossible for polyadenylation to occur during gel filtration in the absence of ATP, but the mRNA might acquire a poly(A) tail during the subsequent incubation in the translation assay, which necessarily contains ATP. To test this possibility, ribo-

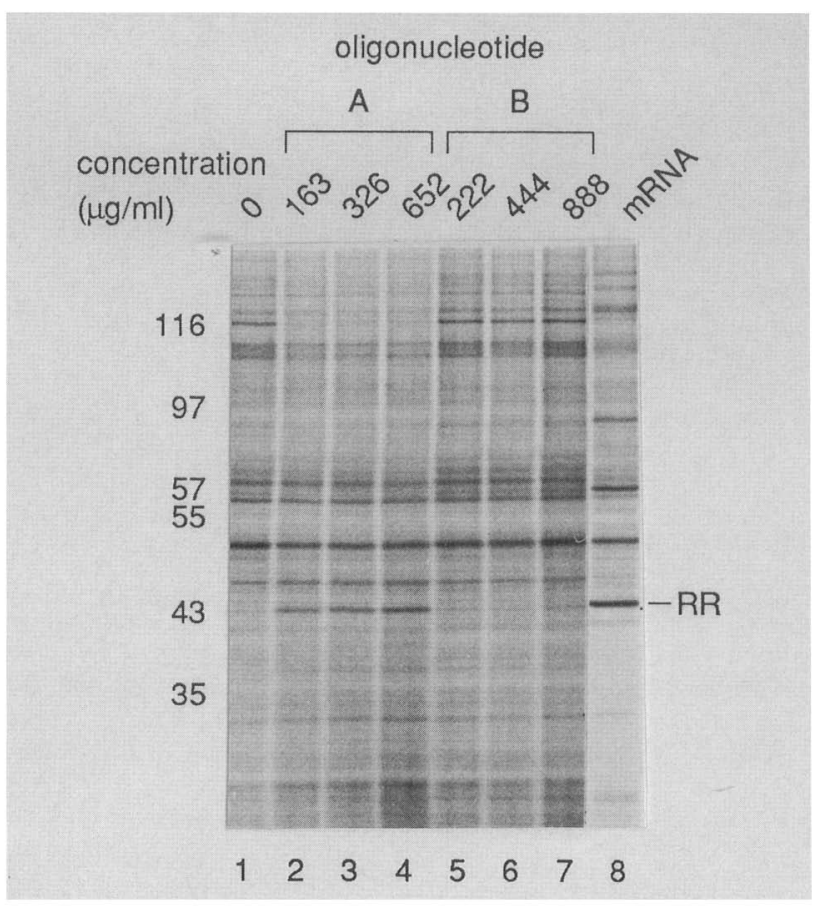

Figure 6. Unmasking by scission of the $3^{\prime}$ UTR using oligodeoxynucleotides and RNase $\mathrm{H}$. Oocyte mRNPs were incubated with the indicated concentrations of oligonucleotides, (location shown in Fig. 3A), together with RNase $\mathrm{H}$, as described in Materials and methods. (Lane 1) Control with no added oligonucleotide; (lanes 2-4) effects of increasing concentrations of oligonucleotide $A_{i}$ (lanes 5-7) oligonucleotide $B_{\text {; }}$ (lane 8 ) positive control showing the translation pattern of phenol-extracted oocyte RNA. The position of ribonucleotide reductase is indicated at right. Oligonucleotide A inhibited the synthesis of a $116-\mathrm{kD}$ polypeptide in the extract in a dose-independent manner, making it unlikely that the increased synthesis of the band at $43 \mathrm{kD}$ interpreted as ribonucleotide reductase was due to translation of the 5 ' fragment of the mRNA for the larger polypeptide. 

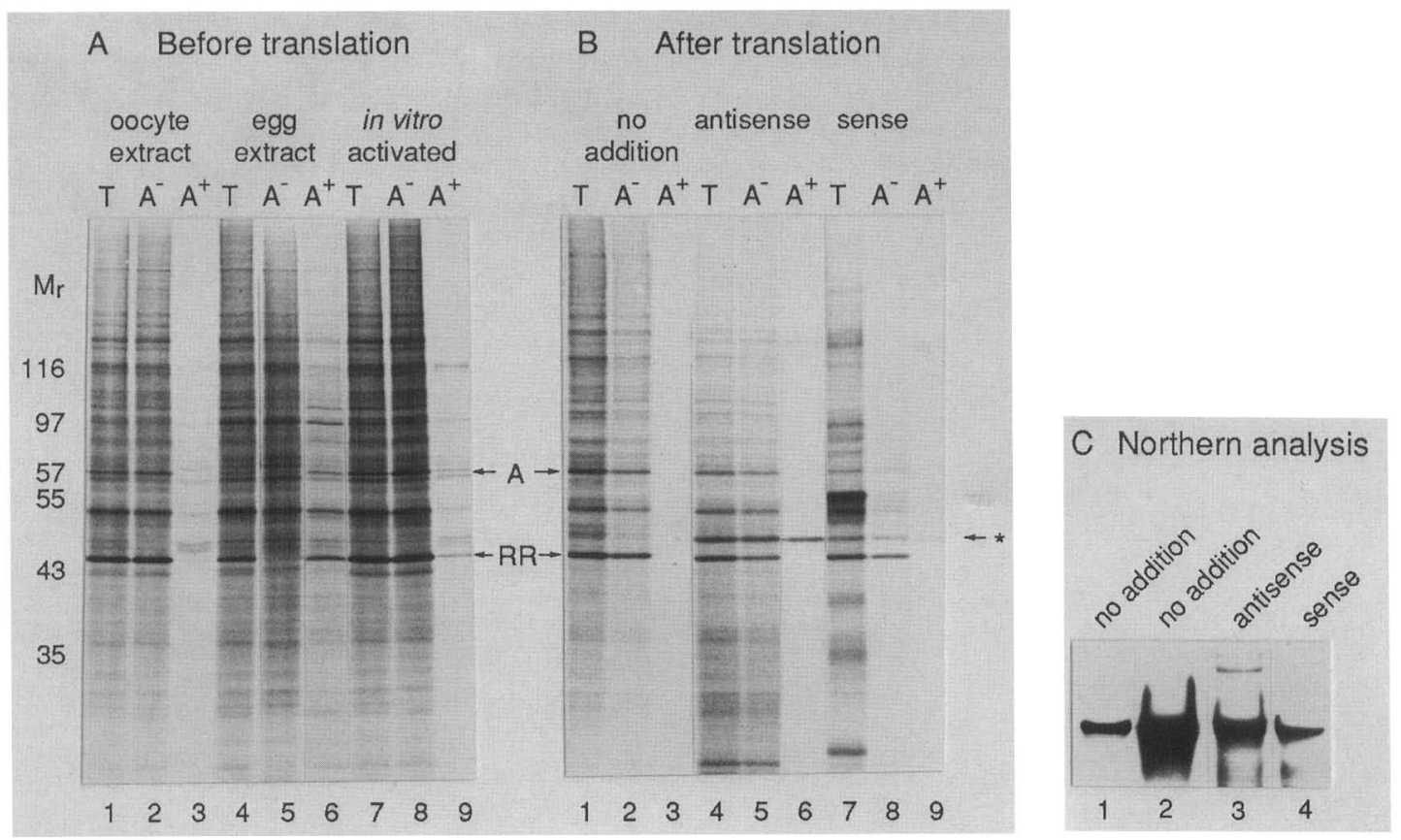

Figure 7. Activation of translation of ribonucleotide reductase mRNA in vitro does not entail polyadenylation or changes in overall size. (A) Total RNA was extracted from clam oocytes (lanes 1-3) or activated eggs (lanes 4-6), or from oocyte extracts that had been activated by gel filtration in $0.5 \mathrm{M} \mathrm{KCl}$ (lanes 7-9). RNA was chromatographed on oligo(dT)-cellulose into poly(A) ${ }^{+}$and poly(A)fractions that were assayed by translation in the reticulocyte lysate. $(B)$ The unmasking assay as described in Fig. 3 was carried out with $3^{\prime}$ antisense transcript (lanes 4-6), 3' sense transcript (lanes 7-9), or with no competitor transcript (lanes 1-3). Following incubation of the mRNPs for $60 \mathrm{~min}$ in the reticulocyte lysate unmasking assay, RNA was extracted (an aliquot was kept for Northern blot analysis) and separated into poly $(\mathrm{A})^{+}$and poly $(\mathrm{A})^{-}$fractions, which gave the translation products shown in $B$. The endogenous reticulocyte band, (lanes $4-9)$ is indicated by an asterisk $\left({ }^{*}\right) .(C)$ Northern blot analysis of RNA recovered from the unmasking assays described above. The RNAs, separated on a 1\% agarose-glyoxal gel, were blotted onto Hybond $\mathrm{N}$ and probed with a ${ }^{32} \mathrm{P}-\mathrm{labeled}$ antisense RNA transcript from clone 3 (Fig. 5A). (Lanes 1 and 2) No additions (two different exposures); (lane 3) antisense 3' RNA; (lane 4) sense 3' RNA.

nucleotide reductase mRNA was activated by $3^{\prime}$ UTR antisense RNA as usual. Control extracts, with no added transcript RNA or with 3' UTR sense RNA added, were also translated. RNA was extracted at the end of the incubation and separated into $\operatorname{poly}(\mathrm{A})^{-}$and $\operatorname{poly}(\mathrm{A})^{+}$ classes by oligo(dT)-cellulose chromatography. In all cases, irrespective of its previous translational state, ribonucleotide reductase mRNA was found in the poly(A) ${ }^{-}$class (Fig. 7B, lanes 1-9). The recovery of mRNA seemed to be reduced when any synthetic transcripts were added (also see Fig. 7C). We also noted the appearance of additional bands or, rather, bands of altered size in the mixed lysate supplemented with the $3^{\prime}$ UTR sense transcript (Fig. 7B, lanes 7 and 8); we do not know their origin.

The re-extracted RNAs were also analyzed by Northern blotting to see whether addition of the antisense transcript resulted in shortening of the $3^{\prime}$-noncoding region by the action of double-stranded (ds) RNase activity. Ribonucleotide reductase mRNA ran at the expected position of $1.7 \mathrm{~kb}$ in all three cases (Fig. 7C, lanes 1-4). In the presence of added synthetic RNA (lanes 3 and 4), some degradation of the mRNA was evident, as the translation assays had suggested (Fig. 7B). In the case of the antisense transcript, we observed larger bands that presumably corresponded to the mRNA partially hybridized to the antisense transcript and resistant to glyoxal treatment. We conclude that unmasking of ribonucleotide reductase mRNA in vitro is not accompanied by significant changes in size or polyadenylation state.

\section{Cyclin A mRNA can also be unmasked by antisense $3^{\prime}$-noncoding RNA}

To test whether antisense transcripts could unmask any other maternal clam mRNA, we isolated the full-length 1.3-kb-long 3'-noncoding region of cyclin A mRNA by the polymerase chain reaction (PCR) technique (see Materials and methods). The resulting plasmids were transcribed with T7 RNA polymerase to give sense and antisense RNAs which were tested in an unmasking assay. A potential complication of this assay is that the masking of cyclin A mRNA in these systems is leakier than ribonucleotide reductase mRNA (or it may be that an unrelated protein migrates in a similar position on one-dimensional gels; see Fig. 3B). Nevertheless, the antisense RNA transcript led to a clear and specific unmasking of cyclin A mRNA translation, whereas the sense transcript of this region of cyclin A mRNA did not 
(Fig. 8, lanes 5 and 4, respectively). Scanning densitometry of the peak showed that cyclin A synthesis was stimulated between four- and fivefold in three separate experiments. It is important to note that the active antisense transcripts for cyclin A and ribonucleotide reductase were quite specific for their cognate mRNAs.

Preliminary experiments have implicated a short central portion of the 1.3-kb long 3' UTR of cyclin A mRNA in unmasking (not shown). In Figure 9 we indicate the locations and list the sequences of the "unmasking boxes" of both ribonucleotide reductase and cyclin A mRNAs. As expected from the specificity of the antisense transcript experiments, comparison between the two sequences did not reveal any long stretches of homology. The two short elements UUUUA and YAGUG occur more than once in both sequences, and a stretch of 9 bases, GUGCAAUAA, is the longest completely conserved sequence that occurs in both boxes. As yet we have no evidence that any of these motifs are involved in translational regulation.

\section{Discussion}

We show that the mRNAs for ribonucleotide reductase and cyclin A, which are translationally repressedmasked - in clam oocytes, can be unmasked (nonspecifically) by gel filtering cell-free extracts in high salt. More significantly, these mRNAs can be specifically un-

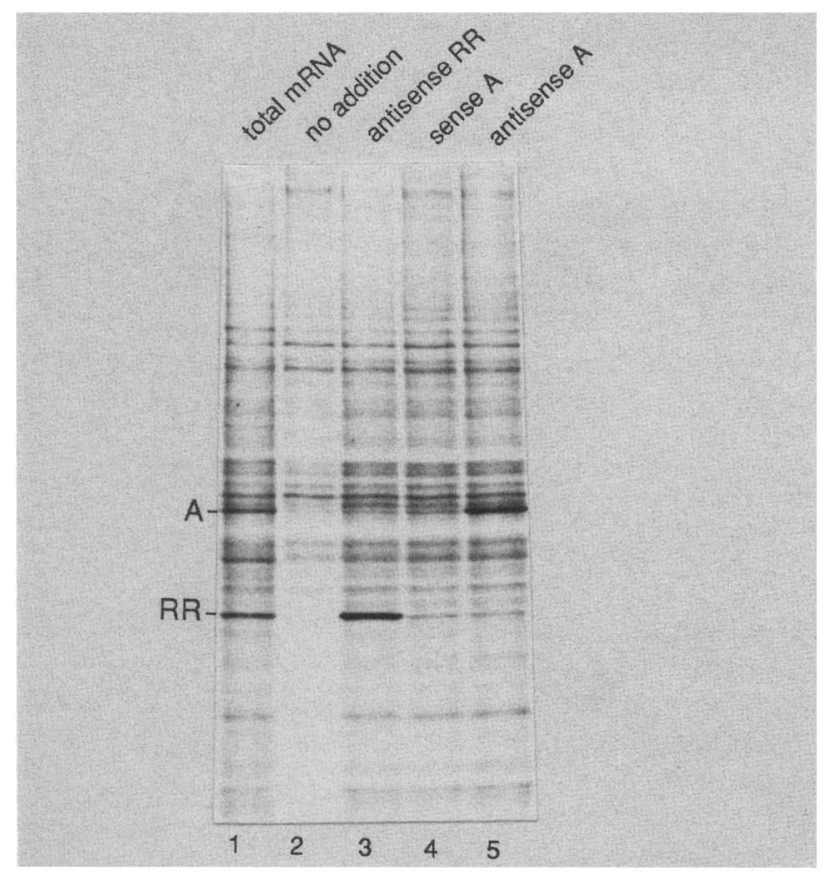

Figure 8. Cyclin A mRNA can also be specifically unmasked by $3^{\prime}$-noncoding antisense RNA. (Lanes 1 and 2) The pattern of translation given by total oocyte RNA and mRNP, respectively; (lanes 3 and 5 ) the activation of ribonucleotide reductase and cyclin A mRNAs by their cognate antisense $3^{\prime}$ RNAs; (lane 4) the result of adding cyclin A $3^{\prime}$ sense RNA to the oocyte mRNP.
Ribonucleotide reductase

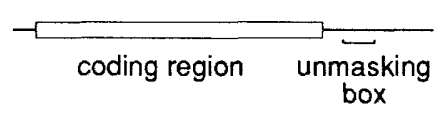

Cyclin A

coding region unmasking

Ribonucleotide reductase 'unmasking box'

CUGGAAGCGUUGUUGUUUCAUUGGUUUUAAAACAUUUUAAUAA

UAGUGCAAAUUA UAAUUUUACUUUUUUAUDAGUGUGCAAUAADU

GCAUGAAUUAUGAUUUUACCGGUUAUUUAUUUUUGUAAAUUUG

GUUUG

Cyclin A 'unmasking box'

AAGCUUUAUUGCGCAAUCAGGAUUUUAAUUCGUGUUUDAGUGU

AGACUCUUAUAUACAGJGGAUUUGCUGUUUUUAAAAUGACUUG

AGAUAGUGAUUCAUCAGUGACAUGCUUUUAOAGUGCAAUAAA

Figure 9. Comparison of the minimal unmasking sequences of ribonucleotide reductase and cyclin A mRNAs. Maps of ribonucleotide reductase and cyclin A mRNAs are shown with their coding regions indicated by boxes. In the $3^{\prime}$ UTR, the regions implicated in unmasking the respective mRNAs in the antisense RNA experiments are bracketed. The sequences of these unmasking boxes are given below. The ribonucleotide reductase sequence starts at position 1284 (Standart et al. 1985); the cyclin A sequence starts at position 1928 (Swenson et al. 1986). The repeated motifs UUUUA and YAGUG are underlined and bold, respectively, and the longest perfect match, GUGCAAUAA, between the two regions is underlined by dots. The complete sequences of clam ribonucleotide reductase and cyclin A have been submitted to the EMBL Database, accession numbers X55125 and X55127, respectively.

masked by annealing with antisense RNA complementary to their 3' UTRs. Detachment of the entire 3' UTR using antisense oligonucleotides and RNase $\mathrm{H}$ also resulted in significant activation of translation of ribonucleotide reductase mRNA. The minimum active region of the 3' UTR of ribonucleotide reductase mRNA has been defined as 134 nucleotides between residues 83 and 217 of the 3' UTR, counting the first nucleotide after the termination codon as +1 . The core active region may be smaller than this. The only similarity between the $3^{\prime}$ UTR of ribonucleotide reductase and that of cyclin A mRNA, apart from the short sequence motifs shown in Figure 9, appear to be runs of 3-7 $\mathrm{A}$ and $\mathrm{U}$ residues. This may explain why both poly(A) and poly(U) showed detectable activity in the competitive unmasking assay (Fig. 3B). As yet, no clear conserved secondary structure features have been identified. However, the regions of 
the $3^{\prime}$ UTRs that appear to comprise the masking element of these two abundant maternal mRNAs are relatively short (120-140 bases) and should permit the characterization of specific RNA-binding proteins using gel retardation and cross-linking assays (Konarska and Sharp 1986; Leibold and Munro 1988).

What is the interpretation of these results? It seems reasonable to assume that maternal mRNAs are masked by repressor protein(s) that are presumably modified, removed, or destroyed by proteolysis at the appropriate time in development. The activation of translation of the oocyte mRNP by phenol extraction or gel filtration in high salt - treatments that would tend to remove RNA-associated proteins - is consistent with this view. Activation by antisense RNA was completely unexpected, however, and can probably be explained by the formation of double-stranded RNA that displaces the repressor protein(s) in much the same way as gel filtration. The masking proteins must bind to specific sequences or structures found in the critical region in the $3^{\prime}$ UTR, and the double-stranded helix forms a different and unrecognizable structure. We were surprised that sense-strand competitor RNAs were so poorly active in the competitive unmasking assay. Several explanations are possible; perhaps the synthetic RNAs do not fold correctly, or perhaps proteins are bound to noncontiguous stretches of the mRNA so that displacement from one site leaves them still bound to another. It is also possible that the repressor proteins are present in excess to the mRNA in the extract, so that addition of the sense transcript did not relieve inhibition. Unfortunately, antisense transcripts of the 5' UTR inhibit translation in their own right, so the failure of these transcripts to activate translation of ribonucleotide reductase mRNA (Fig. 3B) does not exclude the (likely) possibility that masking also involves regions in the $5^{\prime}$ end of the mRNA.

The activation of ribonucleotide reductase mRNA by antisense RNA in vitro was not accompanied by polyadenylation or gross size changes. Thus, the antisense RNA activation mechanism appears to be different from that described recently in the case of tissue plasminogen activator (tPA) mRNA, which is translationally activated during mouse oocyte maturation. Strickland et al. (1988) microinjected antisense RNA complementary to the terminal 103 residues of the 3' UTR into mouse oocytes. This inhibited tPA mRNA activation and resulted in shortening of the mRNA by an endogenous doublestranded RNase. The antisense RNA was later shown to prevent the polyadenylation that was necessary for activation (Vassali et al. 1989). In the case of Xenopus maternal mRNA "G10," it appeared that the act of polyadenylation rather than the presence of a poly $(\mathrm{A})$ tail per se was required for microinjected synthetic G10 mRNA to be mobilized into polysomes during oocyte maturation (McGrew et al. 1989). These two instances of translational activation in living cells emphasize the importance of the poly(A) tail or the act of polyadenylation in maternal mRNA activation. The temporal correlation between polysomal recruitment and poly(A) lengthening of a wide variety of mRNAs in developmental and other systems also supports this view (for review, see Jackson and Standart 1990|. In our in vitro system, however, it appears that translational activation of masked maternal mRNA and polyadenylation are not functionally linked. It is likely that the two events are interrelated in intact cells; for example, polyadenylation may alter the structure of the $3^{\prime}$ end of mRNA in such a way as to allow unmasking. Alternatively, removal of masking proteins may expose the sites for polyadenylation.

We have not tested whether the dsRNA adenosine deaminating activity described by Bass and Weintraub (1988) and Kimelman and Kirchner (1989) is active in clam cell-free extracts. If it is, and addition of antisense RNA leads to such modification, it does not affect our conclusion that the control of translation can be affected by sequences in the $3^{\prime}$-untranslated regions of masked mRNA. We should make it clear that there is no evidence that the physiological process of unmasking involves antisense RNA in clams, and we make no claim that it might; it seems more likely that alterations to the putative repressor proteins are involved.

Although the finding that the masking elements are located in the $3^{\prime}$ UTR regions of clam mRNAs was unexpected, cases of translational regulation by $3^{\prime}$ UTR sequences are beginning to emerge. For example, Kruys et al. (1989) showed that removal of certain UA-rich sequences from the $3^{\prime}$ UTRs of interferon, granulocyte-macrophage colony-stimulating factor, and c-fos mRNAs strongly stimulated their translation in Xenopus oocytes. Recently, a human cell line has been described in which creatine kinase mRNA is present and apparently associated with polysomes, but inactive. Translational activation was achieved by expression of the 3' UTR sequence in trans (Ch'ng et al. 1990).

Considering that ribosomes are thought to bind to mRNA starting at the $5^{\prime}$ cap and "scanning" down the message to the first AUG, it is understandable that sequences in the 5' UTR have often been implicated in the regulatory mechanism of translationally controlled mRNAs (Kozak 1989). Examples of such regulation include Drosophila heat shock mRNAs (for review, see Linquist 1987), yeast GCN4 mRNAs (Hinnebusch 1988), ferritin mRNA (Munro and Eisenstein 1989), and ribosomal protein mRNAs (Mariottini and Amaldi 1990; Steel and Jacobson 1990). So, how might proteins bound at the $3^{\prime}$ end prevent ribosomes from entering at the $5^{\prime}$ end of the mRNA? Presumably, there must be interactions between the two ends of the mRNA. We imagine that the proteins that bind to the 3' UTR interact with proteins bound to sequences in the $5^{\prime}$ UTR, combining to create a structure that ribosomes ignore. Although our present results do not yet provide the answer as to how unmasking is brought about in living cells, the assay system we describe provides a convenient test system for exploring the mechanism.

\section{Materials and methods}

Buffers

All buffers were made as follows. Buffer T: $300 \mathrm{~mm}$ glycine, 120 
$\mathrm{mM}$ potassium gluconate, $100 \mathrm{~mm}$ taurine, $40 \mathrm{mM} \mathrm{NaCl}, 10$ mM EGTA, $2.5 \mathrm{~mm} \mathrm{MgCl}_{2}, 100 \mathrm{~mm}$ HEPES; adjust to $\mathrm{pH} 7.2$ with KOH. LSB (low-salt buffer): $25 \mathrm{mM} \mathrm{KCl}, 10 \mathrm{mM} \mathrm{NaCl}, 1.1$ $\mathrm{mM} \mathrm{MgCl}_{2}, 0.1 \mathrm{mM}$ EDTA, $10 \mathrm{mM}$ HEPES; adjust to $\mathrm{pH} 7.2$ with $\mathrm{KOH}$. HSB (high-salt buffer): LSB plus $0.5 \mathrm{M} \mathrm{KCl}$. ExoIII buffer: $50 \mathrm{~mm}$ Tris- $\mathrm{HCl}(\mathrm{pH} 8.0), 5 \mathrm{~mm} \mathrm{MgCl}, 1 \mathrm{~mm}$ DTT. ExoVII buffer: $70 \mathrm{~mm}$ potassium phosphate $(\mathrm{pH} 7.9), 8.3 \mathrm{~mm}$ EDTA, 1 mM 2-mercaptoethanol.

\section{Preparation and gel filtration of clam postmitochondrial extracts}

Postmitochondrial extracts of oocytes and $\mathrm{KCl}$-activated oocytes were prepared from homogenates of clam oocytes or eggs in buffer $\mathrm{T}$ as described by Standart et al. (1986). Only batches of oocytes with intact germinal vesicles or embryos that had undergone $100 \%$ activation were used. Extracts were frozen in liquid nitrogen, stored at $-80^{\circ} \mathrm{C}$, and clarified by brief centrifugation at $12,000 \mathrm{rpm}$ at $4^{\circ} \mathrm{C}$ after thawing.

Postmitochondrial extracts were gel filtered on Sepharose CL6B (Pharmacia) in either LSB or HSB. Approximately $1.2 \mathrm{ml}$ of clarified extract (adjusted to $0.5 \mathrm{M} \mathrm{KCl}$ if necessary) was loaded onto a $20-\mathrm{ml}$ column at $4^{\circ} \mathrm{C}$. The absorbance at $260 \mathrm{~nm}$ of each fraction was measured, and the excluded peak containing mRNAs and ribosomes was pooled. Aliquots were stored in liquid nitrogen.

\section{Translation assays}

Total RNA was translated at a final concentration of $700 \mu \mathrm{g} / \mathrm{ml}$ in the nuclease-treated reticulocyte lysate (Jackson and Hunt 1983|. Typically, 1 or $2 \mu \mathrm{l}$ of RNA was added to $8 \mu \mathrm{l}$ of reticulocyte lysate mix with $\left.0.5 \mathrm{mCi} / \mathrm{ml}{ }^{35} \mathrm{~S}\right]$ methionine. In the mixed clam lysate/reticulocyte lysate assays, $2 \mu \mathrm{l}$ of clam postmitochondrial extract or the mRNP peaks from gel filtration columns $(\sim 3-4 \mathrm{mg} / \mathrm{ml}$ RNA) was added to $8 \mu$ l of mRNA-dependent lysate gel filtered on Sephadex G-25 (Pharmacia) in LSB (Jackson et al. 1983). For unmasking experiments we used the excluded material from a low-salt Sepharose CL6-B column, because this gave more active translation and the same product pattern as crude postmitochondrial extracts. Competitor RNAs were added at an approximate final concentration of 25-50 $\mu \mathrm{g} / \mathrm{ml}$. Samples were processed for analysis on SDS-polyacrylamide gels as described by Jackson and Hunt (1983).

To obtain oligonucleotide-mediated scission of mRNA, RNase $\mathrm{H}$ was added to extracts at a final concentration of 100 $\mathrm{U} / \mathrm{ml}$ in the presence of concentrations of antisense oligonucleotides ranging from $163-888 \mu \mathrm{g} / \mathrm{ml}$. The sequence of oligonucleotide A was 5'-CAACAACGCTTCCAG-3' |residues 83-97 with respect to the end of the coding region/ and oligonucleotide B was 5'-ATCAAAGGATACAATCTC-3' (280-296).

\section{pGEM subclones of ribonucleotide reductase cDNA}

An almost full-length cDNA of ribonucleotide reductase mRNA has recently been sequenced; it is missing only $14 \mathrm{nu}$ cleotides from the $5^{\prime}$ end, as judged by direct sequencing of the mRNA (N. Standart et al., in prep.). Various portions of the 1.7$\mathrm{kb}$ cDNA (flanked at each end by EcoRI linkers) were subcloned into PGEM1 and pGEM2 vectors (Promega) as follows (nucleotide positions in brackets; numbering according to N. Standart et al., in prep.). S5: Sense 5'-noncoding region subclone. The 5' EcoRI-BgIII fragment (15-213) was isolated and cut with AluI to give a large fragment $(33-213)$, which was ligated to the following pair of complementary phosphorylated oligonucleotides, 5'-AATTCTTAACTTTTGATATTCGTTCTG'TCAAGT
AG-3' and 5'-CTACTTGACAGAACGAATATCAAAAGTT AAG-3', which reconstructed the complete 5 '-noncoding region of ribonucleotide reductase mRNA with an EcoRI overhang at the $5^{\prime}$ end. This insert was ligated into pGEM1, cut with EcoRI and BamHI. When linearized with HindIII and transcribed with T7 RNA polymerase a sense transcript was obtained, containing 94 bases of 5'-noncoding region and 118 bases of the amino-terminal protein sequence. A5: Antisense $5^{\prime}$-noncoding region subclone. The EcoRI-HindIII insert of S5 was subcloned into pGEM2 cut with EcoRI and HindIII. SC and AC: Sense and antisense-coding region subclones. A DdeI fragment (residues $382-538$ ) was end-filled and ligated into SmaIcut pGEM1. The resulting plasmids were sequenced to determine their orientation, linearized with $\mathrm{BamHI}$, and transcribed with T7 RNA polymerase. S3-1 and A3-1: Sense and antisense 3 '-noncoding region subclones. The DdeI (1232)-EcoRI fragment was end-filled and subcloned into SmaI-cut pGEM1. The resulting plasmids were sequenced to determine their orientation. A3-2: The truncated transcript of A3-1 was generated after cutting with NdeI.

\section{PCR cloning of the $3^{\prime}$ noncoding of cyclin A mRNA}

Single-stranded cDNA was prepared from activated clam oocyte poly $(\mathrm{A})^{+}$RNA and amplified by the PCR technique (Saiki et al. 1988) using a 5' oligonucleotide corresponding to the last 17 bases of cyclin A-coding region (Swenson et al. 1986; 5'TAGCACTCCTTGCTTTG-3') and oligo(dT/ $\left.\right|_{24-30}$ as the $3^{\prime}$ oligonucleotide. The resulting cDNA of $\sim 1.3 \mathrm{~kb}$ was end-repaired and subcloned into the SmaI site of pGEMl. Double-stranded DNA sequencing was used to determine the orientation of the plasmids. The plasmids were linearized with BamHI before transcription with T7 RNA polymerase.

\section{Exonuclease III deletion clones}

The procedure of Henikoff (1987) was used to generate a set of deletion clones of the ribonucleotide reductase mRNA 3 '-noncoding region. We are grateful to Mike Lewis, MRC Laboratory of Molecular Biology, for his advice and protocol.

To obtain the $5^{\prime}$ deletion set of clones, plasmid A3-1 /see Fig. 3A) was cut with PstI and BamHI in the polylinker region upstream of the insert, and the cut DNA was digested with exonuclease III (Boehringer Mannheim). Samples were taken every $30 \mathrm{sec}$ and incubated with exonuclease VII (BRL). The DNAs from three time points were pooled, repaired with DNA polymerase, and religated. The resulting plasmids were screened for size after cutting with HindIII and EcoRI and sequenced to determine the precise end points of the deletions.

To obtain the $3^{\prime}$ deletion set of clones, plasmid 5 (Fig. 5A) was cut with $N d e$ I in the insert (pGEM does not contain an NdeI site) and digested with exonucleases III and VII as above. The extent of digestion was checked by agarose gel electrophoresis following digestion with HindIII. Pooled DNA was digested with Sacl to remove the distal NdeI fragments, end-repaired, and ligated as described above. The resulting plasmids were sequenced using the T7 primer.

\section{In vitro transcription}

Linearized plasmids were transcribed in a final volume of $50 \mu \mathrm{l}$. Reactions contained $1 \mathrm{~mm}$ each $\mathrm{rNTP}, 40 \mathrm{~mm}$ Tris- $\mathrm{HCl}(\mathrm{pH}$ 8.0), $15 \mathrm{~mm} \mathrm{MgCl}_{2}, 1 \mathrm{~mm}$ DTT, 1 -2 $\mu$ g DNA, $0.3 \mathrm{U} / \mu \mathrm{l}$ T7 RNA polymerase (prepared by S. Mackie in this laboratory), and 50 
units of RNase inhibitor (Boehringer Mannheim) for $90 \mathrm{~min}$ at $37^{\circ} \mathrm{C}$. The efficiency of transcription was checked by agarose gel electrophoresis; we routinely obtained at least 10-20 times as much RNA as template DNA. The remainder of the reaction was extracted with phenol and chloroform, precipitated with ethanol, and resuspended in water to a final RNA concentration of $\sim 1 \mu \mathrm{g} / \mathrm{ml}$.

\section{Acknowledgments}

We are particularly grateful to Richard Jackson for suggesting that the unmasking assay might work and for many other stimulating discussions, to Joan Ruderman for encouragement and hospitality in Woods Hole, and to the MRC for a grant. Oligonucleotide synthesis was performed by Mike Weldon and supported by the Wellcome Trust.

The publication costs of this article were defrayed in part by payment of page charges. This article must therefore be hereby marked "advertisement" in accordance with 18 USC section 1734 solely to indicate this fact.

\section{References}

Aziz, N. and H.N. Munro. 1987. Iron regulates ferritin mRNA translation through a segment of its $5^{\prime}$ untranslated region. Proc. Natl. Acad. Sci. 84: 8478-8482.

Bass, B.L. and H. Weintraub. 1988. An unwinding activity that covalently modifies its double-stranded RNA substrate. Cell 55: 1089-1098.

Bradford, M.M. 1976. A rapid and sensitive method for the quantitation of microgram quantities of protein utilizing the principle of protein-dye binding. Anal. Biochem. 72: 248254.

Caldwell, D.C. and C.P. Emerson. 1985. The role of cap methylation in the translational activation of stored maternal histone mRNA in sea urchin embryos. Cell 42: 691-700.

Ch'ng, J.L.C., D.L. Shoemaker, P. Schimmel, and E.W. Holmes. 1990. Reversal of creatine kinase translational repression by 3' untranslated sequences. Science 248: 1003-1006.

Davidson, E.H. 1986. Gene activity in early development. Academic Press, Orlando, Florida.

Driever, W. and C. Nüsslein-Volhard. 1988. A gradient of bicoid protein in Drosophila embryos. Cell 54: 83-93.

Dworkin, M.B., A. Shrutkowski, and E. Dworkin-Rastl. 1985. Mobilization of specific maternal mRNA species into polysomes after fertilization in Xenopus laevis. Proc. Natl. Acad. Sci. 82: 7636-7640.

Evans, T., E. Rosenthal, J. Youngbloom, D. Distal, and T. Hunt. 1983. Cyclin: A protein specified by maternal mRNA in sea urchin eggs that is destroyed at each cleavage division. Cell 33: 389-396.

Grainger, J.L. and M.M. Winkler. 1987. Fertilization triggers unmasking of maternal mRNAs in sea urchin eggs. Mol. Cell. Biol. 7: 3947-3954.

Grainger, J.L., A. von Brunn, and M.W. Winkler. 1986. Transient synthesis of a specific set of proteins during the rapid cleavage phase of sea urchin development. Dev. Biol. 114: $403-415$.

Henikoff, S. 1987. Unidirectional digestion with exonuclease III in DNA sequence analysis. Methods Enzymol. 155: 156165.

Hentze, M.W., T.A. Roualt, S.W. Caughman, A. Dancis, J.B. Harford, and R.D. Klausner. 1987. A cis-acting element is necessary and sufficient for translational regulation of human ferritin expression in response to iron. Proc. Natl. Acad. Sci. 84: 6730-6734.
Hinnebusch, A.G. 1988. Mechanisms of gene regulation in the general control of amino acid biosynthesis in Saccharomyces cerevisiae. Microbiol. Rev. 52: 248-273.

Huarte, J., D. Belin, A. Vassali, S. Strickland, and J.-D. Vassali. 1987. Meiotic maturation of mouse oocytes triggers the translation and polyadenylation of dormant tissue-type plasminogen activator mRNA. Genes Dev. 1: 1201-1211.

Hyman, L. and M. Wormington. 1988. Translational inactivation of ribosomal protein mRNAs during Xenopus oocyte maturation. Genes Dev. 2: 598-605.

Ilan, J. and J. Ilan. 1978. Translation of maternal messenger ribonucleoprotein particles from sea urchin in a cell-free system from unfertilized eggs and product analysis. Dev. Biol. 66: 375-385.

Jackson, R.J. and T Hunt. 1983. Preparation and use of nuclease-treated rabbit reticulocytes for the translation of eukaryotic mRNA. Methods Enzymol. 96: 50-74.

Jackson, R.J., and N. Standart. 1990. Do the poly(A) tail and 3' untranslated region control mRNA translation? Cell 62: 15-24.

Jackson, R.J., E.A. Campbell, P. Herbert, and T. Hunt. 1983. The preparation and properties of gel-filtered rabbit-reticulocyte lysate protein-synthesis systems. Eur. I. Biochem. 131: 289-301.

Jenkins, N.A., J.F. Kaumeyer, E. Young, and R.A. Raff. 1978. A test for masked message: The template activity of messenger ribonucleoprotein particles isolated from sea urchin eggs. Dev. Biol. 63: 279-298.

Kimelman, D. and M.W. Kirschner. 1989. An antisense mRNA directs the covalent modification of the transcript encoding fibroblast growth factor in Xenopus oocytes. Cell 59: 687696.

Konarska, M.M. and P.A. Sharp. 1986. Electrophoretic separation of complexes involved in the splicing of precursors to mRNAs. Cell 46: 845-855.

Kozak, M. 1989. The scanning model for translation: An update. J. Cell Biol. 108: 229-241.

Kruys, V., O. Marinx, G. Shaw, J. Deschamps, and G. Huez. 1989. Translational blockade imposed by cytokine-derived UA-rich sequences. Science 245: 852-855.

Leibold, E.A. and H.N. Munro. 1988. Cytoplasmic protein binds in vitro to a highly conserved sequence in the $5^{\prime}$ untranslated region of ferritin heavy- and light-chain mRNAs. Proc. Natl. Acad. Sci. 85: 2171-2175.

Linquist, S. 1987. Translational regulation in the heat-shock response of Drosophila cells. In Translational regulation of gene expression (ed. I. Ilan), pp. 187-207. Plenum Press, New York.

Mariottini, P. and F. Amaldi. 1990. The 5' untranslated region of mRNA for ribosomal protein S19 is involved in its translational regulation during Xenopus development. Mol. Cell. Biol. 10: 816-822.

McGrew, L.L., E. Dworkin-Rastl, M.B. Dworkin, and J.D. Richter. 1989. Poly(A) elongation during Xenopus oocyte maturation is required for translational recruitment and is mediated by a short sequence element. Genes Dev. 3: 803815.

Moon, R.T., M.V. Danilchik, and M.B. Hille. 1982. An assessment of the masked message hypothesis: Sea urchin egg messenger ribonucleoprotein complexes are efficient templates for in vitro protein synthesis. Dev. Biol. 93: 389-403.

Munro, H.N. and R.S. Eisenstein. 1989. Translational control: The ferritin story. Curr. Opin. Cell Biol. 1: 1154-1167.

Paynton, B.V., R. Rempel, and R. Bachvarova. 1988. Changes in state of adenylation and time course of degradation of ma- 
ternal mRNAs during oocyte maturation and early embryonic development in the mouse. Dev. Biol. 129: 304-314.

Richter, J.D. 1987. Molecular mechanisms of translational control during the early development of Xenopus laevis. In Translational regulation of gene expression (ed. I. Ilan), pp. 111-139. Plenum Press, New York.

Rosenthal, E. and F. Wilt. 1987. Selective messenger RNA translation in marine invertebrate oocytes, eggs, and zygotes. In Translational regulation of gene expression (ed. I. Ilan|, pp. 87-1 10. Plenum Press, New York.

Rosenthal, E., T. Hunt, and J.V. Ruderman. 1980. Selective translation of mRNA controls the pattern of protein synthesis during early development of the surf clam, Spisula solidissima. Cell 20: 487-496.

Rosenthal, E.T., B.P. Brandhorst, and J. Ruderman. 1982. Translationally mediated changes in patterns of protein synthesis during maturation of starfish oocytes. Dev. Biol. 91: 215220.

Rosenthal, E.T., T. Tansey, and J.V. Ruderman. 1983. Sequence-specific adenylations and deadenylations accompany changes in the translation of maternal messenger RNA after fertilization in Spisula oocytes. I. Mol. Biol. 166: 309327.

Saiki, R.K., D.H. Gelfand, S. Stoffel, S. Scharf, R. Higuchi, G.T. Horn, K.B. Mullis, and H.A. Ehrlich. 1988. Primer-directed enzymatic amplification of DNA with a polymerase. Science 239: 487-491.

Spirin, A.S. 1966. On "masked" forms of messenger RNA in early embryogenesis and in other differentiating systems. Curr. Top. Dev. Biol. 1: 1-38.

Standart, N.M., S.J. Bray, E.L. George, T. Hunt, and J.V. Ruderman. 1985. The small subunit of ribonucleotide reductase is encoded by one of the most abundant translationally regulated maternal RNAs in clam and sea urchin eggs. $I$. Cell Biol. 100: 1968-1976.

Standart, N., T. Hunt, and J.V. Ruderman. 1986. Differential accumulation of ribonucleotide reductase subunits in clam oocytes: The large subunit is stored as a polypeptide, the small subunit as untranslated mRNA. I. Cell Biol. 103: $2129-2136$.

Standart, N., J. Minshull, J. Pines, and T. Hunt. 1987. Cyclin synthesis, modification and destruction during meiotic maturation of the starfish oocyte. Dev. Biol. 124: 248-258.

Steel, L.F. and A. Jacobson. 1990. Sequence elements which affect mRNA translational activity in developing Dictyostelium cells. Dev. Genet. (in press).

Strickland, S., J. Huarte, D. Belin, A. Vassali, R.J. Rickles, and J.-D. Vassali. 1988. Antisense RNA directed against the 3' noncoding region prevents dormant mRNA activation in mouse oocytes. Science 241: 680-684.

Swenson, K.I., K.M. Farrell, and J.V. Ruderman. 1986. The clam embryo protein cyclin $A$ induces entry into $M$ phase and the resumption of meiosis in Xenopus oocytes. Cell 47: 861870.

Vassali, J-D., J. Huarte, D. Belin, P. Gubler, A. Vassali, M.L. O'Connell, L. Parton, R.J. Rickles, and S. Strickland. 1989. Regulated polyadenylation controls mRNA translation during meiotic maturation of mouse oocytes. Genes Dev. 3: $2163-2171$.

Walden, W.E., M.M. Patino, and L. Gaffield. 1989. Purification of a specific repressor of ferritin mRNA translation from rabbit liver. J. Biol. Chem. 264: 13765-13769.

Westendorf, J.M., K.I. Swenson, and J.V. Ruderman. 1989. The role of cyclin B in meiosis I. J. Cell Biol. 108: 1431-1444. 


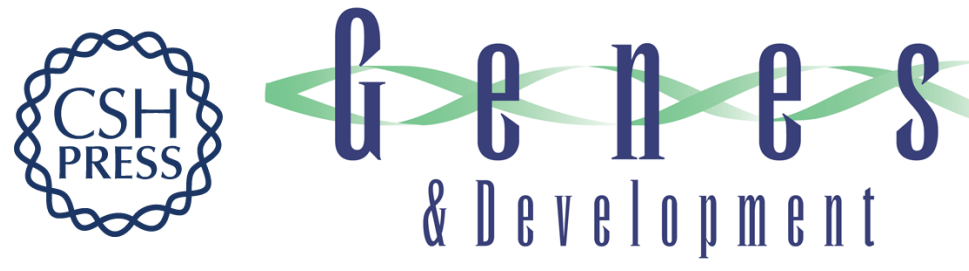

\section{Maternal mRNA from clam oocytes can be specifically unmasked in vitro by antisense RNA complementary to the 3'-untranslated region.}

N Standart, M Dale, E Stewart, et al.

Genes Dev. 1990, 4:

Access the most recent version at doi:10.1101/gad.4.12a.2157

References This article cites 43 articles, 20 of which can be accessed free at:

http://genesdev.cshlp.org/content/4/12a/2157.full.html\#ref-list-1

License

Email Alerting

Service

Receive free email alerts when new articles cite this article - sign up in the box at the top right corner of the article or click here.

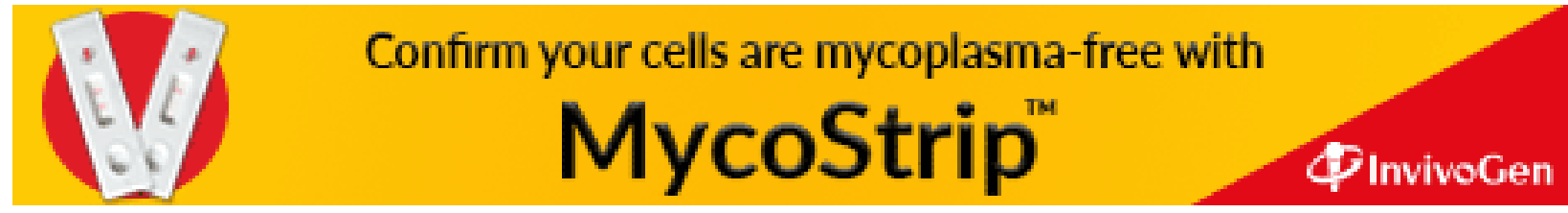

